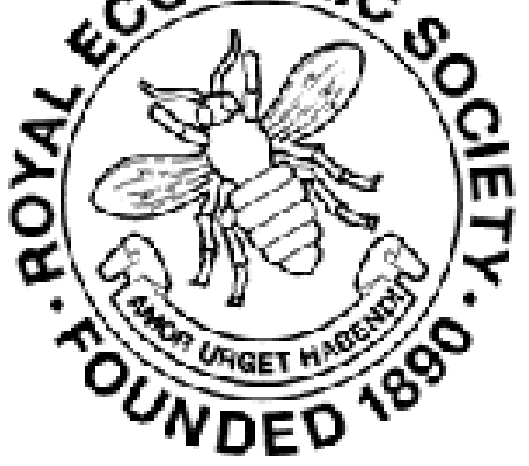

The Gold Policy of the United States

Author(s): Ira B. Cross

Source: The Economic Journal, Vol. 29, No. 113 (Mar., 1919), pp. 25-36

Published by: Wiley on behalf of the Royal Economic Society

Stable URL: http://www.jstor.org/stable/2223137

Accessed: 27-06-2016 05:10 UTC

Your use of the JSTOR archive indicates your acceptance of the Terms \& Conditions of Use, available at

http://about.jstor.org/terms

JSTOR is a not-for-profit service that helps scholars, researchers, and students discover, use, and build upon a wide range of content in a trusted digital archive. We use information technology and tools to increase productivity and facilitate new forms of scholarship. For more information about JSTOR, please contact support@jstor.org.

Royal Economic Society, Wiley are collaborating with JSTOR to digitize, preserve and extend access to The Economic Journal 


\section{THE GOLD POLICY OF THE UNITED STATES}

Prior to the enactment of the Federal Reserve Law in December, 1913, the banking system of the United States lacked unity and definite purpose. Approximately 7,600 national banks were chartered under one law-a federal law-without any central authoritative body to guide their activities or to assist them in conserving the interests of the banking world or of the nation as a whole, while even greater lack of unity and purpose characterised the 25,000 State banks chartered under the various laws of forty-eight different States.

With the nation's gold hoardings scattered among these 32,600 banks, there could be no control exercised in preventing an overexpansion of loans on new additions to our gold stock, in shifting supplies of gold about the country so as to meet pressing local needs, or in effectively regulating the gold flow in connection with foreign trade. The situation was at complete variance with accepted European practices. Nor, on the other hand, were satisfactory means provided for the creation of an elastic currency which might in times of financial stringency assist in concentrating the country's gold holdings and in conserving their use. In times past banks had been compelled to resort to the use of clearing-house loan certificates issued by the local clearing-houses to their members upon the deposit of proper collateral, such as stocks, bonds, commercial paper, etc. These were employed solely, except in 1907,1 in the settlement of clearing-house balances. As a result of the crisis of 1907, Congress passed the Aldrich-Vreeland Law, which enabled national banks to form "national currency associations" and to issue through them the so-called "emergency currency" secured by bonds other than those of the United States Government and commercial paper. Conditions resulting from the declaration of war in August, 1914, necessitated the amendment of this law so as to facilitate the issuance of this emergency currency, and during the next few months forty-one national currency associations issued $\$ 384,485,000$

1 In 1907, fifty-one clearing houses issued $\$ 255,536,300$ clearing-house loan certificates for general circulation. 
of it. At the same time twelve clearing-house associations issued $\$ 211,778,000$ loan certificates, but for use only in clearing-house transactions.

These limping half-way measures were most unsatisfactory in every regard, and it was, in part, for the purpose of improving the conditions mentioned that the Federal Reserve system was created.

The Federal Reserve Law, as originally enacted in 1913, made certain definite reforms possible in the above connections, but subsequent amendments to that law and the enactment of other measures by Congress enabled the Federal Reserve Board, cooperating with the Secretary of the Treasury, to be most active, and successfully so, during the late war in concentrating the nation's store of gold, in conserving its use, and in controlling its outflow. The following discussion is concerned with the methods employed and the results secured.

One of the most important changes made by the Federal Reserve Law that greatly assisted in improving the situation had to do with the reserve requirements of the member banks, first, as to their amount, and, secondly, as to their places of deposit. ${ }^{1}$ Under the national banking system no distinction had been made between demand and time deposits. National banks had also been divided into three groups, depending primarily upon the size of the city in which the bank was located. New York, Chicago, and St. Louis were classed as "central reserve" cities; about fifty other cities were known as "reserve" cities; while the remainder were designated "country" cities. National banks in the first group had been required to keep on hand a reserve of 25 per cent. against all deposits; in the second group the same reserve had been required, but one-half of it could be deposited with national banks in eities of the first group; while, in the last group, a reserve of 15 per cent. had been required, but threefifths of it could be deposited in national banks located in cities of the other two groups. As can easily be seen, this system of reserves inevitably encouraged the piling up of bank reserves in cities of the first group, and primarily in New York.

The Federal Reserve Law, however, distinguished between demand and time deposits, and also greatly reduced the reserve requirements for all three groups. Reserves against demand deposits were fixed at 18 per cent. for member banks in central

1 All national banks were compelled to join the system or give up their national charters, while State banks were permitted to become members if they desired to do so. 
reserve cities, at 15 per cent. for reserve cities, and at 12 per cent. for all other cities, while reserves against time deposits in all groups were fixed at 5 per cent. This change in the reserve requirements released approximately $\$ 465,000,000$ (to a considerable extent gold) previously held for that purpose. In order to assist in concentrating the country's gold hoardings, the Federal Reserve Law required member banks to keep their reserves in only two places, i.e., part in the Federal reserve bank of the district in which the member bank was located, and part in their own vaults, the exact proportions being fixed by the provisions of the law. Three years were given in which to shift from the old system of scattered reserves to that of more concentrated reserves. Before the three years had passed, however, the situation had changed. World-war conditions resulting in huge imports of gold, in greater demands upon our banking system for extension of credit, and in the possibility of an unrestricted gold outflow at the conclusion of the war or possibly before, made the revision of certain features of the Federal reserve system not only possible, but also imperative. These changes were effected by the amendments of June 21st, 1917. Reserve requirements were thereby further reduced from 18 to 13 per cent. for central reserve city banks, from 15 to 10 per cent. for reserve city banks, and from 12 to 7 per cent. for country city banks, while for all groups the reserves against time deposits were reduced from 5 to 3 per cent. Another amendment compelled all member banks to keep their reserves wholly in the Federal reserve bank of their respective districts, thus bringing about, for the first time in the history of banking in the United States, a partial concentration of reserves, but only, of course, for member banks. A third amendment permitted non-member banks to avail themselves of the facilities of the Federal reserve check clearing and collection system by opening accounts with the Federal reserve banks for exchange or collection purposes. Within sixty days after these changes had become effective the gold and lawful money ${ }^{1}$ held by the Federal reserve banks had increased $\$ 487,955,000$, while their holdings of free gold, i.e., the surplus over required reserves, had increased approximately $\$ 300,000,000$.

Attempts were also made through other amendments, by the solicitations of the Federal reserve banks, and by Presidential proclamation, to induce State banks to become members of the

1 Lawful money is any money that may be used by member banks for reserve purposes, and excludes only National bank notes, Federal reserve bank notes. and Federal reserve notes. 
Federal reserve system and thus assist in the mobilisation of gold holdings through the concentration of reserves in the Federal reserve banks. Up to January 1st, 1919, approximately 900 State banks, with total resources of over $\$ 7,000,000,000$, had entered the system, thus giving the Federal reserve system control over about 80 per cent. of the commercial banking resources of the nation.

The country's gold was also conserved by other measures, such as officially requesting that gold coins be not used for gifts, that gold coin counting machines be not employed because of the resulting abrasion, etc., while the Government itself even went so far as to cease the minting of gold coins in October, 1917. Typical of the whole-hearted spirit of co-operation with which the efforts of the Federal Reserve Board were met was the action of the Treasurer of the State of California, who in February, 1918, in face of law and long-standing custom, agreed to accept the cashier's checks of the Federal reserve bank of that district, or Federal reserve notes instead of gold in payment of taxes, thus releasing to that Federal reserve bank several millions of gold which would otherwise have been held as so much "dead" metal in the State's vaults.

To remedy certain of the evils in the national banking system, to which reference has been made above, the Federal Reserve Law authorised the Federal reserve banks to issue two kinds of paper money, i.e., Federal reserve notes and Federal reserve banknotes. The latter are secured by United States bonds or other forms of indebtedness of the Federal Government and were not designed to supply any element of elasticity to our monetary system. They are supposed gradually to replace the national bank-note circulation. The law permits any national bank to retire any or all of its bank-notes until December 23rd, 1935. In order to provide a stable market for the sale of the Government bonds with which the national bank-notes are secured, and to induce, not to compel, the banks to retire their circulation, the law permits the Secretary of the Treasury, if necessary, to order the Federal reserve banks in the aggregate to purchase annually not more than $\$ 25,000,000$ of these bonds at par plus accrued interest. The Federal reserve banks from time to time purchased their required quota of Government bonds, but it was not until March, 1916, that the first Federal reserve bank-notes were issued by the Kansas City Bank. The Dallas Bank followed in September. Each had issued approximately $\$ 6,000,000$ of this new kind of bank-note. By December of that year, however, they had 
all been retired from circulation, but not cancelled, although during the year the national bank-notes in circulation had decreased \$44,511,968. In 1917 the Kansas City Bank again put its $\$ 6,000,000$ of Federal reserve bank-notes into circulation along with an additional $\$ 2,000,000$, converting. them into gold and thereby increasing its gold holdings, although the Federal reserve bank-notes had not been originally devised with any idea of their being used in that capacity. During 1918 certain developments made it possible for them to be again so used.

While the war was on the United States was faced with the necessity of paying for goods imported from the Orient, especially from India. This unfavourable balance of trade, it was pointed out, could easily be met by payments of silver rather than of gold, provided the necessary silver could be obtained. Acting at the request of the Treasury Department, Congress, on April 23rd, 1918 , passed a law permitting the breaking up of not to exceed $350,000,000$ silver dollars, which were then being held in the United States Treasury as security behind an equal amount of silver certificates. This silver was then to be sold at a minimum price of $\$ 1.00$ per fine ounce to American importers for remittance to Oriental countries. ${ }^{1}$ Federal reserve banks were at the same time called upon to issue Federal reserve bank-notes to take the place of the retired silver certificates, such notes to be secured by United States bonds, or, if desired, by one-year Treasury notes, or United States certificates of indebtedness, the maturity of the latter to be extended from time to time as the Secretary of the Treasury deemed necessary. The retirement of the silver certificates and the breaking up of the silver dollars proceeded rapidly. It is interesting to note, however, that the Federal reserve banknotes were not issued anywhere nearly as rapidly as the deficiency in the country's currency. was created by the retirement of both silver certificates and national bank-notes. Thus during 1918 the amount of Federal reserve bank-notes in circulation increased as follows: January 1st, $\$ 8,000,000$; April 19th, $\$ 7,895,000$; June 14 th, $\$ 10,000,000$; August 30 th, $\$ 20,000,000$; October 10th, $\$ 52,031,000$; December 6th, $\$ 92,799,000$; December 27th, $\$ 117,122,000$; January 3rd, 1919, $\$ 120,267,000$. During the same time, however, $\$ 187,984,764$ silver certificates had been retired. National bank-note circulation had also decreased $\$ 445,775,000$ from October 31st, 1914, the date nearest the actual establishment of the Federal reserve system for which data are available, to December 27th, 1918, the date of the latest report of

1 On August 10th: 1918, the price was raised to $\$ 1.01 \frac{1}{2}$ per fine ounce. 
the U.S. Comptroller of Currency, although during that time approximately 200 new national banks had been organised. ${ }^{1}$

The second kind of currency authorised by the Federal Reserve Law, i.e., the Federal reserve notes, have been of tremendous service to the country in connection with gold mobilisation, although devised originally only as a means of supplying the needed element of elasticity to our monetary system. The Federal Reserve Law of 1913 provided that the reserve notes should be secured by 100 per cent. collateral in the shape of commercial paper which had been rediscounted by the Federal reserve bank, and by 40 per cent. of gold reserve. In spite of this explicit provision, however, the Federal reserve banks, almost immediately upon organisation, began to issue these notes against 100 per cent. gold security, continuing to do so until June, 1917. They justified their action on the ground that the step in question was deemed necessary in order that the mobilisation of the country's gold might be aided. As a result of the issuance of the Federal reserve notes under the conditions mentioned, and because of other matters already discussed above, especially those relating to the changed requirements concerning the amounts and the location of the reserves of the member banks, the gold holdings of the Federal reserve banks increased from $\$ 230,912,000$ on December 4th, 1914, to $\$ 1,050,890,000$ on June 15th, 1917. On June 21st, 1917, Congress amended the reserve law so as to authorise the issuance of reserve notes against 100 per cent. of gold or gold certificates. The amendments also permitted the Federal reserve banks to substitute rediscounted commercial paper for the gold so held, provided the collateral never exceeded 60 per cent. of the face value of the notes issued, and also provided the remaining 40 per cent. should always be gold or gold certificates. Thus a Federal reserve bank with $\$ 100,000,000$ reserve notes backed by $\$ 100,000,000$ gold could, by substituting $\$ 60,000,000$ rediscounted paper and retaining $\$ 40,000,000$ of the gold security, still have $\$ 100,000,000$ reserve notes in circulation, thus freeing $\$ 60,000,000$ gold for use elsewhere, or it could add $\$ 150,000,000$ rediscounted paper to its original $\$ 100,000,000$ gold and thus be able to put $\$ 250,000,000$ reserve notes in circulation.

As noted above, the Federal reserve notes were, until June, 1917 , secured by practically 100 per cent. of gold, and consequently played no part in any inflation that may have taken place

1 From what has just been stated, one must not get the idea that the per capita circulation in the country has decreased as a result of the withdrawal of the silver certificates and the National bank notes. In fact it had rather noticeably increased from $\$ 35$ in 1914 , to $\$ 55.76$ on January 1st, 1919. 
up to that time. The Federal reserve banks were very active in paying out reserve notes for gold and gold certificates, thus aiding greatly in the mobilisation of our gold holdings. Strong pressure was brought to bear upon banks, both State and national, and liberal inducements were held out to them to exchange their gold and gold certificates for reserve notes. The public was also urged to accept and use the reserve notes in all business transactions. Especially in the Western States, where gold still remained the current medium of exchange, was a vigorous appeal made to the banks, and through the banks to the public, that they "patriotically" accept the reserve notes and thus assist the Federal reserve banks in their task of gold mobilisation. This policy was almost universally successful, and gold disappeared from general circulation.

Federal reserve notes and Federal reserve bank-notes are not classed as "lawful money" by the Federal Reserve Law, and thus cannot be used by member banks for reserve against deposits. At first, also, State legislatures would not authorise their use in that connection by State banks, but as the situation grew more serious they changed their attitude and enacted legislation permitting their use for reserve purposes, thereby enabling the State banks and trust companies to exchange their gold for these notes, primarily for the reserve notes, and thus to co-operate in the task of maintaining an adequate gold basis for our rapidly-growing credit structure. As a consequence of that situation, $\$ 1.00$ of gold, with the addition of $\$ 1.50$ of rediscounted commercial paper, could be used by a Federal reserve bank as security for the issuance of $\$ 2.50$ of Federal reserve notes, and if a State bank used these notes as reserves against its deposits, the dollar of gold would thus support approximately $\$ 10$ of credit. This may appear to be an undue and possibly an unsafe extension of credit upon such a slim gold basis, but it should be remembered that the Federal reserve notes are obligations of the United States Government, although issued by the privately-owned Federal reserve banks, that they are secured by at least 40 per cent. of gold and 60 per cent. of rediscounted commercial paper, and that they are a first lien upon the assets of the issuing Federal reserve bank, a lien upon the assets of the bank that rediscounted the commercial paper at the Federal reserve bank, and a lien also upon the assets of the drawer of the commercial paper. More adequate security need not be required.

Almost immediately after the passage of the 1917 amendments, which, as has been noted, greatly reduced the amount of 
commercial paper required as collateral behind the reserve notes, the situation changed greatly, not only as to the amount of the reserve notes issued, but also as to the extent of the security furnished. The amount of reserve notes in actual circulation increased from $\$ 491,615,000$ on June 15 th 1917 , to $\$ 1,246,488,000$ on December 28th, 1917, to $\$ 1,677,951,000$ on June 21st, 1918, to $\$ 2,555,215,000$ on November $22 \mathrm{nd}, 1918$, and to $\$ 2,648,605,000$ on January 3rd, 1919. At the same time the gold security held behind them decreased rapidly, being respectively 94.4 per cent., 64.3 per cent., 58.9 per cent., 50.8 per cent., and 52.8 per cent. on the dates mentioned. ${ }^{1}$ It must not be overlooked, however, that the amount of rediscounted commercial paper held against these notes in excess of the sum legally required equalled $\$ 1,122,000$ on June 15 th, $1917, \$ 46,804,000$ on December 28 th, $1917, \$ 279,517,000$ on June 21st, 1918, and $\$ 406,946,000$ on November 22nd, 1918. Similar data are not available at this date for January 3rd, 1919.

As a consequence of the measures above described, not only was the total gold stock held by the Federal reserve banks increased from $\$ 1,050,890,000$ on June 15th, 1917, to $\$ 1,924,373,000$ on June 21 st, 1918 , and to $\$ 2,092,694,000$ on January 2nd, 1919, ${ }^{2}$ thus representing the strongest collection of commercial banking assets in the world, but by means of the Federal reserve notes the gold resources of the reserve system were made to do much greater service than would otherwise have been possible. It is estimated that the Federal reserve banks now hold more than two-thirds of the monetary stock of gold in the country.

Since the signing of the armistice the amount of Federal reserve notes in actual circulation has noticeably decreased. Thus, within three weeks after December 27th, 1918, at which time they had reached their maximum amount, they fell from $\$ 2,685,244,000$ to $\$ 2,512,973,000$. It has also been noticed that large amounts of gold and gold certificates have been brought from their hidingplaces by those who had hoarded them for possible needs during the war. This reappearance of the hoarded gold may also assist the Federal reserve banks in their further accumulation of gold, if in the future they deem it advisable or necessary to continue their past polities in that regard.

The events which followed in quick succession upon the

1 The lowest ratio of gold reserve held against reserve notes occurred on October 10th, 1918, when it fell to 49.6 per cent.

2 On January 17th, 1919, the Federal reserve banks held $\$ 2,102,557,000$ gold. 
declaration of war in 1914 brought the financiers of the United States face to face with the necessity of properly safeguarding the country and its financial interests against the dangers of an excessive gold drain. The complete derangement of foreign exchange operations, the dumping of foreign-owned stocks and bonds upon the American markets, and the necessity of paying almost immediately an indebtedness abroad of approximately $\$ 150,000,000$ in the face of the then existing European moratoria, all made inevitable the tremendous exportation of gold during the first few months of the war. ${ }^{1}$ In July and August, 1914, gold to the extent of $\$ 51,795,041$ left the country, exchange rates rose to unheard-of levels, and the situation became panicky in the extreme. To aid in meeting the American crisis, the Bank of England agreed to accept gold shipped to Ottawa for its account with the Minister of Finance and to give credit on its London books for the sums involved. A gold pool of New York bankers was also formed to take care of New York's maturing obligations held abroad, totalling about $\$ 80,000,000$. This pool subsequently shipped approximately $\$ 35,000,000$ gold to Ottawa. On September 4th, 1914, the Secretary of the Treasury called a meeting of bankers and clearing-house representatives to formulate a plan of relief for the country as a whole. The result was the formation of a National Gold Pool, which established a gold fund of $\$ 100,000,000$, subscribed to by State and national banks throughout the country. The amount was over-subscribed, and but one call (for $\$ 25,000,000$ ) was made. Shipments of gold to Ottawa were continued until the shifting currents of trade and the lapsing of the European moratoria brought exchange rates back to normal. In time the gold flow turned in our favour, as is clearly disclosed by the following table:-

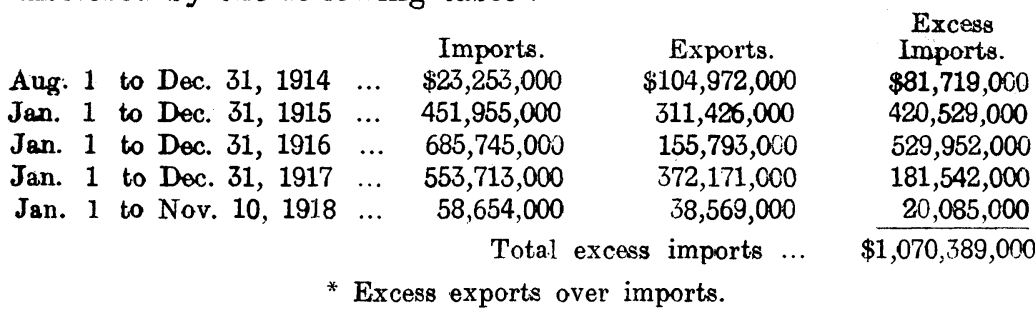

In 1917, however, other nations, primarily neutral countries. began taking gold from us in dangerously large quantities, as is evidenced by the fact that our gold exports increased from $\$ 155,793,000$ in 1916 to $\$ 372,171,000$ in 1917. Inasmuch as it was felt that there was a possibility that some of that gold was

1 Gold exports during June, 1914, had reached $\$ 48,107,000$.

No. 113.-VoL. XXIX. 
finding its way into the hands of our enemies it was deemed advisable that the Government take steps towards controlling the situation. Consequently, on September 7th, 1917, the President issued a proclamation forbidding the exportation of all bullion, coin, or currency, except in accordance with regulations imposed by the Secretary of the Treasury. The administration of the regulations in question was placed by the latter in the hands of the Federal Reserve Board. Applications to export were passed upon by the Federal reserve bank of the district in which the application was made, subject, however, to the approval of the Federal Reserve Board and the Secretary of the Treasury. The Board subsequently established a "Division of Foreign Exchange" under the direction of an able administrator, and drew up a very complete set of regulations covering the exportation of coin, currency, and bullion.

At first practically no restrictions were placed upon the exportation of Canadian gold and currency other than gold. Applications to export silver bullion, American silver coin, and American paper money, excepting only gold and gold certificates, were usually granted. Especially was silver allowed to flow freely to the Orient as a means of paying Oriental balances, although, on August 10th, 1918, the Treasury Department announced that export licences for silver would thereafter be "granted only for civil or military purposes in connection with the prosecution of the war." The Board also took pains to prohibit the "earmarking" of gold for foreign account in the United States. The passage of the "Trading with the Enemy Act" (October 6th, 1917), and a subsequent proclamation by the President (October 12th), further extended the control of the Board and the Secretary of the Treasury over the exportation of bullion, coin, and currency without materially changing the machinery or the regulations already in effect. On January 26th, 1918, the President issued another executive order, compelling all dealers in foreign exchange to secure a licence from the Federal Reserve Board.

During November, 1917, certain branches of trade found it necessary to request the release of considerable amounts of gold. Especially was this true of Mexico and Canada. A conference was held with Canadian bankers, which resulted in the Federal Reserve Board agreeing to release $\$ 25,000,000$ gold prior to July 1 st, 1918, in amounts not to exceed $\$ 10,000,000$ in any one month. This arrangement assisted greatly in stabilising the exchange rates between the two countries. Applications for 
shipments of gold to Mexico were granted only for government account and only when shipments of gold were shown to be necessary to bring certain essential products into the country.

The Indian situation, where dollar exchange, standing at 19.42 per cent. discount in September-October, 1917, was causing serious thought as to what means of satisfactory payment could be provided without resorting to the shipment of gold, was met in part by the measures discussed above. At different times, also, the Secretary of the Treasury made arrangements with representatives of the Indian Government whereby credits aggregating $20,000,000$ rupees were provided and allotted by Federal reserve banks to importers according to their needs. Adverse exchange rates, with the dollar greatly at a discount in neutral countries, made it pressingly urgent that steps be taken to bring matters back to normal, so as to prevent the outflow of gold. Consequently, in January, 1918, an agreement was entered into with Argentina, whereby funds up to $\$ 40,000,000$ were deposited with the Federal reserve bank of New York as a basis for furnishing exchange on that country, the Argentine Government agreeing to pay in Argentina the corresponding amount of pesos at a discount of 3 per cent. below the par of exchange. The United States agreed to ship gold at the end of the war if conditions existing at that time made it necessary to do so. An additional credit of $\$ 60,000,000$ was later provided. A similar agreement, limited to $\$ 5,000,000$, with permission to extend it to $\$ 20,000,000$, was made with Bolivia, while the drafting of like agreements was taken up with Chile, Peru, and Uruguay. In the case of Spain a group of Spanish bankers were induced to open a group credit with certain American bankers to the extent of $250,000,000$ pesetas, while, in case of Switzerland, an arrangement was made with the Government of that country whereby an amount of Swiss currency, sufficient for the needs of the American Expeditionary Forces was provided at par of exchange.

The results of these arrangements were especially gratifying. The discount on dollar exchange in foreign countries, particularly in neutral markets, was materially reduced, in some cases wiped out entirely, thus rendering unnecessary the shipment of gold. Gold exports dropped, and the immediate dangers of a serious gold loss were indefinitely postponed.

With the return of peace it is impossible accurately to predict future developments. Already various restrictions on exchange dealings have been removed by the Government, and the promise made that further privileges will be accorded from time to time 
as conditions warrant. Regardless of what happens, however, the war has taught us many valuable lessons that will be of inestimable service to us in the future. We have devised methods for concentrating the country's gold holdings in the Federal reserve banks and have learned how to use them to an advantage. We have developed the machinery for handling the intricate problems of foreign exchange and gold flow, and have tested it out under the most adverse circumstances. Undoubtedly the coming months, with their ebb and flow of trade, the use of arbitraging practices, and the complete removal of governmental restrictions upon exchange operations, will bring a gradual readjustment of the world's gold supply among the various countries; but it is seriously questioned whether the gold flow that will necessarily follow such readjustment will at any time result in the disturbances with which business, commerce, and finance were affected during the early days of the war before proper methods had been devised for handling the serious situation that had developed.

IrA B. Cross

University of California. 